\title{
Recent studies on the body composition of ruminants
}

\section{By J. F. D. Greenhalgh, University of Aberdeen, School of Agriculture, 58 I King Street, Aberdeen $A B 9$ I $U D$}

The term 'body composition' is not as precisely defined as it might be. Its least equivocal meaning is the chemical composition of the whole body of an animal, but body composition is also used to describe the chemical composition of a part of the body (e.g. the commercial carcass or a part thereof) and also the composition determined by means other than chemical analysis (e.g. by dissection). To the farm-animal nutritionist, information on the chemical composition of the whole animal is of considerable importance, because it can be used to assess the nutrient requirements of the animal. To the human nutritionist, the chemical composition of the edible parts of animals is the measure of greater interest.

The present brief review is concerned mainly with studies of the chemical composition of the empty body, although reference will be made to studies of tissue proportions. The body constituents assayed chemically were traditionally water, fat, ash and protein, although the last named was sometimes determined by difference. Newer analytical techniques for a vast range of constituents could now be applied to animal tissues, but they have rarely been used for the analysis of the complete bodies of farm animals. Values are available for the calcium or phosphorus content of sheep and cattle, but it is difficult to find reliable values for, say, copper or zinc content.

The word 'recent' in the title of this paper is intended to cover approximately the last decade. In 1973 the UK Agricultural Research Council (ARC) re-established a Working Party to define the nutrient requirements of ruminants. One of the first tasks of the Working Party was to bring together all the information it could find on the essential nutrient and energy content of sheep and cattle. The Working Party's report was published in 1980 (ARC, 1980), but its latest references on body composition were dated r974. The Working Party brought together a great mass of data derived by chemical analysis of individual animals, much being provided directly from the files of the laboratories concerned. For the gross constituents (fat, protein, etc) the numbers of animals were impressively large (650 cattle and 1430 sheep) but for mineral elements relatively few values were found. Information was collected from many laboratories scattered around the world, but three major sources can be identified. These were the so-called Missouri and Minnesota studies of cattle made at the beginning of the century (Haecker, 1920; Moulton et al. 1922), a group of extensive studies of sheep made in Australia in the 1960s and 1970 (e.g. Searle, 1970) and work on both sheep and cattle carried out under the direction of the late J. T. Reid at Cornell University (e.g. Burton \& Reid, 1969). When the ARC Working Party was 
conducting its analyses, much of the Cornell work had been published only in the form of theses. Although theses have the merit of including more information, especially values for individual animals, than journal papers, they tend to be restricted in terms of animal numbers and depth of analysis.

The major developments in the study of body composition of ruminants that have occurred in the past ro years may be summarized as follows. There has been a change in interest from sheep (which are cheaper to analyse) to cattle (which are the more important producers of meat). Thus a series of cattle experiments from Cornell has recently been published (Fortin et al. 1980), and a large body of information on cattle has become available from France (Geay, 1984; Robelin \& Geay, 1984) and Germany (Rohr \& Daenicke, 1984). The French and German studies are particularly valuable because they include the late-maturing continental breeds of cattle, such as the Charolais, Simmental and Limousin, that have had a major influence on beef production throughout the world in the last 20 years. Several important studies have been made of the effects of compensatory growth and body composition. There have been significant developments in the control of body composition by the use of nutritional measures, hormones and drugs. Finally, information on body composition has been used as a vital component in the modelling of animal production.

\section{New knowledge of the effects of sex, breed type and plane of nutrition on body composition}

Cattle. The cattle model of ARC (1980) was based on values for steers of a medium-sized breed type (e.g. Hereford \& Friesian) gaining weight at a moderate rate $(0.6 \mathrm{~kg} / \mathrm{d})$. The model also included factors for adjusting estimates of composition according to breed type (small, medium or large), sex and rate of gain. These factors could only be tentative, however, because of the paucity of information. In particular there was a lack of information on the composition of the large continental breeds such as Charolais and Simmental.

Since 1980, the only new information of British origin on the chemical composition of growing cattle has been that of Truscott $e t$ al. (1982). Depicted in Fig. I, this shows reasonable agreement with the all-breed values of ARC (1980); Herefords, as a small breed, being fatter than Friesians at the same empty-body-weight (EBW). Earlier, Jesse et al. (1976) had also produced values for Herefords that agreed well with ARC ( 1980 ) values at heavier live weights.

While ARC ( 1980 ) was in press, several papers appeared on the composition of continental breeds, and it soon became apparent that they differed from cattle analysed previously; the bulls of these breeds, in particular, were capable of gaining rapidly in protein with a restricted deposition of fat. Their failure to conform to the ARC model is illustrated in Fig. 2 (Greenhalgh, I980). Additional information on continental breeds has been provided from East Germany (Flachowsky, 1979a,b) and from South Africa (Meissner, $1988_{3} a, b$ ), which confirms the ability of these breeds to make gains of high protein and low energy content. Meissner $\left(1983_{3} b\right)$ showed that steers of Bos indicus breeds (Bonsmara, Brahman 


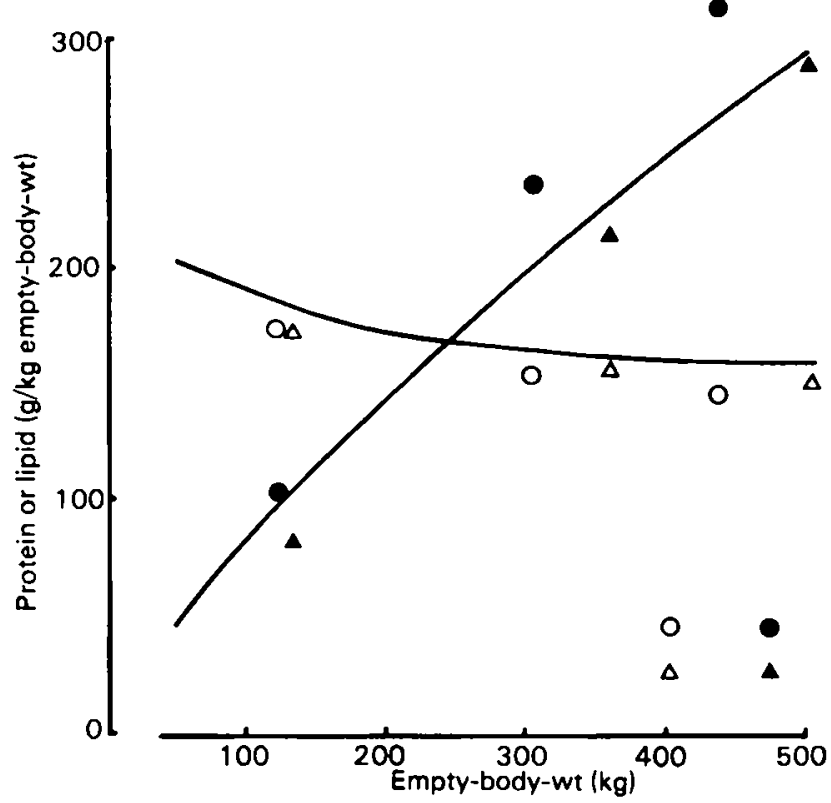

Fig. I. Composition of the empty body of Hereford and Friesian steers (Truscott et al. 1982) in relation to the estimates for all breeds of the Agricultural Research Council (I980). Hereford: (O),

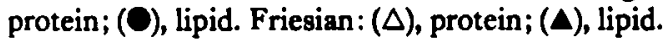

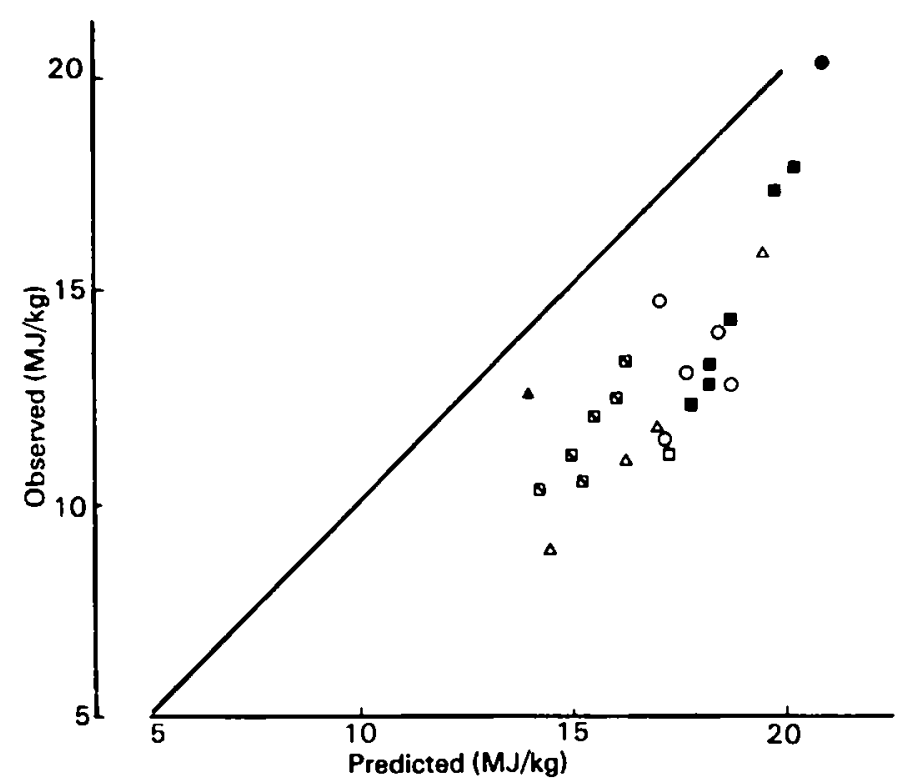

Fig. 2. Energy content of empty-body gain in cattle: recent observations compared with values predicted by the Agricultural Research Council (1980). (O), Hereford steers (Jesse et al. 1976); ( $\square$ ), Charolais $\times$ Salers heifers (Robelin, 1979); ( $\nabla)$, Charolais $\times$ Salers bulls (Robelin, 1979); (O), Friesian bulls (Daenicke \& Rohr, 1978; Robelin et al. 1978; Robelin, 1979); (A), Simmental bulls

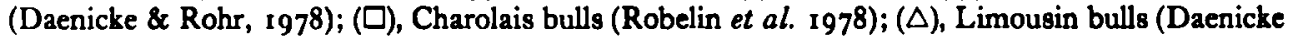
\& Rohr, 1978; Robelin et al. 1979). 
and Afrikander) made gains with an energy content $(17 \cdot 3-18 \cdot 3 \mathrm{MJ} / \mathrm{kg} \mathrm{EBW}$ at 300 kg EBW) that would be expected from their size relative to Charolais, Simmental and Herefords of the same weight.

Meissner $(1983 a)$ has also confirmed that as plane of nutrition (hence rate of gain) increases, the energy content of gain increases; however, there was no clear-cut effect of diet composition (i.e. roughage:concentrate value) on body composition.

Geay \& Robelin (1979) suggested that there was an interaction between energy intake and breed type in their effects on body composition. Large, late-maturing breeds, and especially bulls, show less inclination than smaller breeds to lay down fat as energy intake is increased. At first sight a reduction in the energy content of gain might seem likely to reduce dietary energy requirements. In practice this is not the case, because protein is deposited with lower energetic efficiency than fat; Geay \& Robelin (1979) quote low values for the efficiency factor $k_{f}$ of about 0.30 for continental bulls.

Fortin et al. (1980) at Cornell carried out a large experiment with 159 cattle to determine simultaneously the effects on body composition of breed (Aberdeen Angus and Holstein), sex (bull, steer and heifer) and plane of nutrition (ad lib. or $65-70 \%$ of ad lib. intake). The initial weights of the breeds were on average $171 \mathrm{~kg}$ for Angus cattle and $203 \mathrm{~kg}$ for Holsteins. Allometric relations were derived for each of the twelve treatment groups, the growth coefficients providing estimates of accretion rates. The coefficients are somewhat difficult to compare because of interactions between the treatment factors, and also because some of the breed and sex differences had become established before the experiment began (i.e. there must have been differences between the constant terms of the allometric equations, although these are not given). However, the estimated composition of animals at a fixed EBW ( $325 \mathrm{~kg})$ is given in the paper, and the main effects are summarized in Table I. Exact comparisons with ARC (1980) are not possible, because the growth rates of the cattle are not given. Nevertheless, breed effects are smaller than for ARC (1980), sex effects are similar (although the bulls of Fortin

Table 1. Composition of gains in empty-body-weight made by cattle at $325 \mathrm{~kg}$ in relation to breed, sex and plane of nutrition (from Fortin et al. 1980)

$\begin{array}{lccc} & \begin{array}{c}\text { Protein } \\ (\mathrm{g} / \mathrm{kg})\end{array} & \begin{array}{c}\text { Fat } \\ (\mathrm{g} / \mathrm{kg})\end{array} & \begin{array}{c}\text { Energy } \\ (\mathrm{MJ} / \mathbf{k g})\end{array} \\ \begin{array}{l}\text { Breed: } \\ \text { Aberdeen Angus }\end{array} & 163 & 340 & 17 \cdot 2 \\ \quad \text { Holstein } & 180 & 298 & 16 \cdot 0 \\ \begin{array}{l}\text { Sex: } \\ \text { Bull }\end{array} & & & \\ \text { Steer } & 194 & 227 & 13.5 \\ \quad \text { Heifer } & 170 & 323 & 16.7 \\ \text { Plane: } & 150 & 406 & 19.5 \\ \quad \text { Low } & & & \\ \text { High } & 204 & 214 & 13.2 \\ & 139 & 424 & 19.9\end{array}$


Table 2. Composition at $30 \mathrm{~kg}$ empty-body-roeight of ram lambs of three breed types (Theriez et al. 198I)

Mature wt (kg)

Composition $(\mathrm{g} / \mathrm{kg})$ :

Protein

Fat

\begin{tabular}{cccc}
\multicolumn{4}{c}{ Breed type } \\
$\begin{array}{c}\text { Charmois } \\
75-90\end{array}$ & $\begin{array}{c}\text { Limousin } \\
80-100\end{array}$ & $\begin{array}{c}\text { Berrichon cross } \\
90-110\end{array}$ & ARC (1980) \\
154 & 162 & 165 & - \\
212 & 206 & 179 & 159 \\
& & 166
\end{tabular}

ARC, Agricultural Research Council.

et al. (1980) had gains lower in fat and higher in protein), and plane of nutrition effects are surprisingly large (especially for protein).

The conclusions drawn from the new information for cattle are that although ARC (I980) estimates appear to be applicable to the traditional beef cattle of Britain (i.e. Friesian and Hereford steers), they are not applicable to the larger continental breeds, especially bulls of these breeds. Also, the new data are now sufficiently extensive to allow a re-analysis along the lines used by ARC (1980).

Sheep. The ARC (1980) analysis of data for body composition of sheep produced results that differed in several respects from those for cattle. Although the sheep values came from a wide range of breed types, from Southdowns to Border Leicesters, they were generally combinable between breeds. The only exception was that Merinos were generally fatter than other breeds. There were differences between sexes, but these were not quite as clear cut as in cattle; thus rams and wethers had about the same protein content, although the wethers had a higher fat content. Females were more clearly differentiated, having both less protein and more fat than males or castrates. The final difference between sheep and cattle was that in sheep, body composition was not affected by growth rate.

Theriez et al. (198I) compared three French breed types and found some relation between mature size and composition at a fixed weight (Table 2).

With regard to sex differences, several recent studies have confirmed the large differences in composition between females and males (or castrates) (Ferrell et al. 1979; Robelin \& Theriez, 1981; Theriez et al. 1982; Thompson et al. 1985).

Theriez et al. (1982) reviewed the effects of plane of nutrition or growth rate on body composition of sheep, and concluded that once the milk-feeding period was past, there were no important effects. They fed lambs on diets ranging in roughage:concentrate from $80: 20$ to $20: 80$ and induced growth rates ranging from 267 to $340 \mathrm{~g}$ live weight/d. There were no appreciable differences in body composition, although it should be noted that all growth rates were quite high. Ferrell et al. (1979) grew lambs from I 7 to $66 \mathrm{~kg}$ on diets containing 9.1, 10.0 and II. $7 \mathrm{MJ} / \mathrm{kg}$ dry matter and induced growth rates of 180,230 and $250 \mathrm{~g} / \mathrm{d}$. Body composition was not affected by dietary energy concentration.

Searle et al. (1982) grew Corriedale and Dorset Horn wethers from 19 to 25 or $30 \mathrm{~kg}$ live weight at rates of about 100 or $200 \mathrm{~g} / \mathrm{d}$. Linear relations (i.e. 


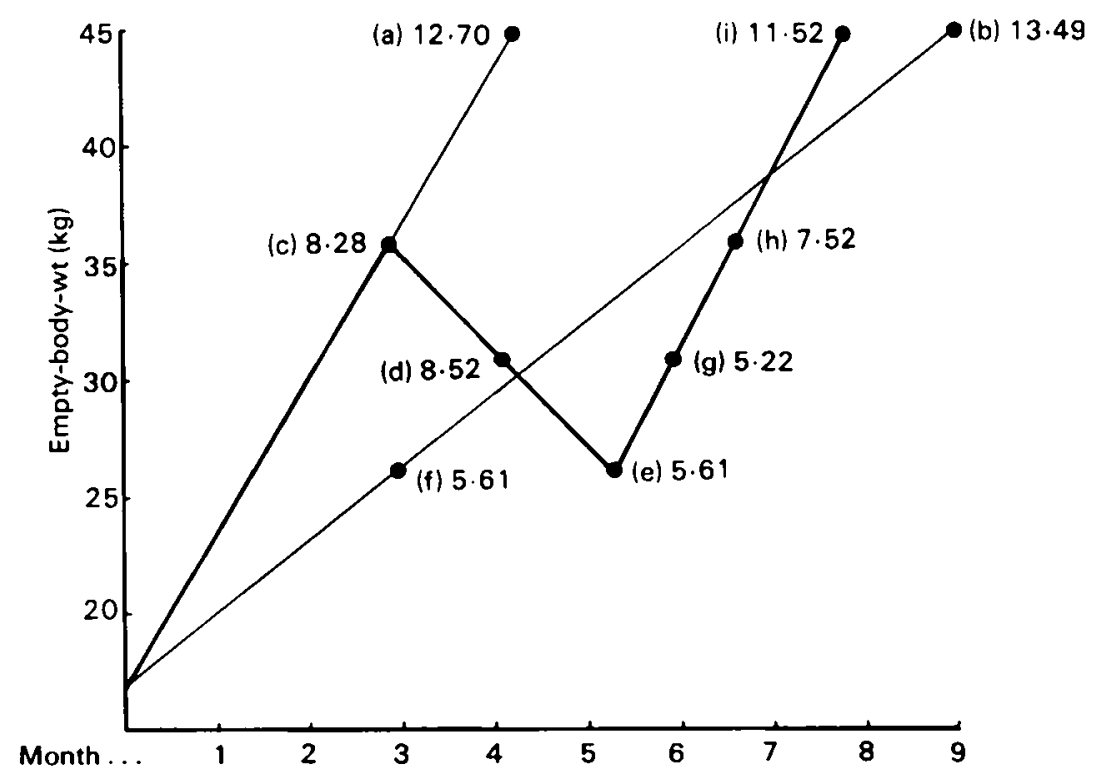

Fig. 3. Weights of fat (kg) in the empty body of lambs following different patterns of growth (Drew \& Reid, 1975).

non-allometric) were calculated between weights of chemical components and EBW. The equations did not differ between breeds; between growth rates there were differences in the regression constants but not in the coefficients, a finding difficult to explain. They concluded that slower-growing animals contained more fat, energy and ash, and less water than the faster-growing.

The main conclusion drawn from new values for sheep is that after live weight, sex is the main determinant of body composition. Plane of nutrition has a smaller effect on composition of sheep than of cattle. Breed effects are likewise smaller in sheep, but justify further study as a means of increasing protein and reducing fat deposition.

\section{Compensatory growth and body composition}

Compensatory growth is the unusually rapid weight increase that occurs when some restriction on growth is removed. The preceding restraint may be (a) mild: growth rate less than maximal, (b) moderate: growth stasis or (c) severe: negative growth (i.e. loss of weight). A question that arises in connection with compensatory growth is whether animals that have reached a given weight by an interrupted route (i.e. restriction followed by compensatory growth) differ in composition from animals that have reached the same weight by an uninterrupted route. The subject has been recently reviewed by O'Donovan (1984).

An example of severe restriction followed by re-alimentation is shown in Fig. 3 . (Drew \& Reid, 1975). The main conclusions drawn are: (I) slow and fast growth to $45 \mathrm{~kg}$ had relatively little effect (c.f. a and b), (2) restriction from $36 \mathrm{~kg}$ (c and d) 
at first had no effect on fat but subsequently reduced it to the level (e) achieved by animals grown slowly but continuously to the same weight (f), (3) in the first stages of re-alimentation, fat content continued to fall ( $\mathrm{e}$ and $\mathrm{g}$ ) but later increased (h and i) to reach levels slightly lower than those of continuously grown animals.

Graham \& Searle (1979) and Thornton et al. (1979) found even less effect of depletion followed by re-alimentation on final body composition of sheep, although the former workers noted that this treatment increased variation in composition. Searle \& Graham (1975) investigated weight stasis followed by re-alimentation in sheep and also found little effect on final body composition.

In cattle, Foot \& Tulloh (1977) found that if Aberdeen Angus steers of $335 \mathrm{~kg}$ live weight were reduced to $280 \mathrm{~kg}$ and then re-alimented to $335 \mathrm{~kg}$ they contained less fat $(82 \mathrm{~g} / \mathrm{kg} \mathrm{EBW})$ than animals which had been held at $335 \mathrm{~kg}$ ( $120 \mathrm{~g} \mathrm{fat} / \mathrm{kg}$ ). Tudor et al. (1980) held Hereford calves at about $40 \mathrm{~kg}$ until $200 \mathrm{~d}$ of age, before re-alimentation. At slaughter, at about $400 \mathrm{~kg}$, these calves contained significantly more fat and less protein and ash than continuously-grown animals, but the degree of stunting was relatively small.

These recent studies on compensatory growth, together with earlier papers, form an impressive series of elegant experiments. They show first and foremost the remarkable ability of ruminants to recover from nutritional deprivation. Compensatory growth is a reality in the sense that gains made early in the period of re-alimentation differ in composition from those made later (or from those made by normally-fed animals), but if animals are given sufficient time to recover, they are able to restore their chemical components to normal proportions.

\section{Modification of body composition}

Studies of body composition can too easily become descriptive rather than constructive. The modeller sees the large variability in body composition as an obstruction to his aim of producing simple models of growth, but the meat producer sees it as an opportunity for improving his animals. Two hundred years ago, British farmers selected animals for their ability to fatten in early life; today they are generally trying to reverse this trend. The most effective way of producing lean (protein) without excessive fat is to use intact males of late maturing (i.e. large) breeds, and to slaughter them while still immature. Selection within breeds for leanness is also possible but has not been practised as assiduously with ruminants as it has with poultry (and pigs). Thompson et al. (1985) compared the body composition of Merino lambs from lines selected for 20 years for high or low weaning weight. At $40 \mathrm{~kg}$ body-weight, their respective protein contents were 142 and $137 \mathrm{~g} / \mathrm{kg}$, and fat contents, 240 and $310 \mathrm{~g} / \mathrm{kg}$. The differences are comparable with those achieved by selection in pigs, the reduction in fat being more marked than the increase in protein.

Body composition may also be modified by nutrition. Barry (1981) gave an abomasal infusion of casein and methionine to lambs growing from about 16 to 24 $\mathrm{kg}$ on fresh-cut ryegrass (Lolium perenne)-white clover (Trifolium repens) herbage (containing $182 \mathrm{~g}$ protein $/ \mathrm{kg}$ dry matter). His results are shown in Table 3. The 
Table 3. Rate and composition of empty-body-weight gain in lambs given abomasal infusions of protein (Barry, $198 \mathrm{r}$ )

$\begin{array}{lccc} & \text { Control } & \text { Protein-infused } & \text { ARC (1980) } \\ \text { Rate of gain }(\mathrm{g} / \mathrm{d}) & 62.0 & 82.4 & - \\ \text { Composition of gain }(\mathrm{g} / \mathrm{kg}): & & & \\ \quad \text { Protein } & 140 & 174 & 148 \\ \text { Fat } & 342 & 225 & 221 \\ \text { Wool growth (g/d) } & 3.9 & 6.6 & -\end{array}$

ARC, Agricultural Research Council.

infusion increased the protein content of gain to a value well above that predicted by ARC ( 1980 ), but reduced the fat content to the predicted level. Waldo \& Tyrrell (I980), working with cattle fed on silages, have also shown a relation between the intake of insoluble protein (i.e. assumed to be escaping rumen degradation) and protein deposition.

An increase in body fat content can also be obtained by supplementation. By raising the lipid content of the diet of lambs to $75 \mathrm{~g} / \mathrm{kg}$, Price (1975) increased the fat content of empty body gain from 400 to $480 \mathrm{~g} / \mathrm{kg}$.

Exogenous hormones, particularly androgens and oestrogens, have been known for many years to increase protein retention or reduce fat deposition, or both, in castrate males (for reviews, see Galbraith \& Topps, 1981 ; Spencer, 1985). Recent interest in hormones has been directed towards growth hormone. Bauman (1984) refers to three trials in which this hormone increased protein deposition in ruminants. Growth hormone, being a peptide, has to be injected daily. Spencer et al. (1983) increased endogenous growth hormone level in sheep by immunization (repeated every 2 weeks) against somatostatin, the hormone which normally suppresses release of growth hormone from the pituitary. Although this treatment increased growth rate it had no effect on carcass composition.

Drugs may also be used to control body composition. There is currently much interest in clenbuterol, a $\beta$-adrenergic agonist, which encourages lipolysis. In man, the fatty acids released are oxidized (in brown adipose tissue) but in farm animals they appear to be utilized to promote protein synthesis (Dalrymple et al. 1984). In lambs, $2 \mathrm{mg}$ clenbuterol $/ \mathrm{kg}$ feed increased live-weight gain and the protein content of the hind-quarter, fat content being correspondingly reduced (Baker et al. 1984) (Table 4). In cattle, $10 \mathrm{mg}$ clenbuterol/d had no effect on growth rate but modified carcass composition as in sheep (Ricks et al. 1984).

Table 4. Growth and carcass composition of lambs given clenbuterol (Baker et al. 1984)

$\begin{array}{lccccc}\text { Clenbuterol in diet }(\mathrm{mg} / \mathrm{kg}) \ldots & 0 & \mathrm{I} & 10 & 100 & \text { SE } \\ \text { Live-weight gain }(\mathrm{g} / \mathrm{d}) & 196 & 180 & 195 & 209 & 2.8 \\ \begin{array}{l}\text { Hind-quarter analysis }(\mathrm{g} / \mathrm{kg}): \\ \quad \text { Protein }\end{array} & 175 & 192 & 196 & 192 & 1.0 \\ \text { Fat } & 211 & 168 & 154 & 163 & 4.3\end{array}$


The coccidiostat monensin is used as a growth promoter in ruminants and its effect on the composition of empty-body gain in Friesian bulls was studied by Daenicke et al. (1982). Groups of twelve animals had equal intakes of feed and metabolizable energy, with or without $30 \mathrm{mg}$ monensin/ $\mathrm{kg}$ feed. The growth promoter increased the fat content of gains from 238 to $292 \mathrm{~g} / \mathrm{kg}$ and energy content from 13.2 to $15.3 \mathrm{MJ} / \mathrm{kg}$, but had no effect on protein content ( 173 or 175 $\mathrm{g} / \mathrm{kg})$.

\section{Models of body composition}

Fox \& Black (1984) have recently described a system for predicting body composition and growth rate in growing cattle that is in several respects similar to the ARC ( 1980 ) system. Net energy requirements for empty-body gain are based on an analysis by Simpfendorfer (1984) of the Missouri and Minnesota data, which are considered to apply to castrate males of average-sized beef breeds. These values are adjusted for sex (heifers and bulls) and frame size (on a scale from $x$ to 9). The adjustments are made in a rather complicated way, by adjusting the actual weight of an animal to the weight of an average-frame castrate at which the two would have had the same body composition; thus a $400 \mathrm{~kg}$ heifer of average frame is considered to have the same empty-body composition as a $500 \mathrm{~kg}$ castrate $(288 \mathrm{~g}$ fat and $165 \mathrm{~g}$ protein $/ \mathrm{kg}$ ). Some values from this system are compared with those from ARC (1980) in Table 5; the agreement between them is remarkably close (even to the point of medium-breed heifers being given the same values as small-breed steers). Fox \& Black's (r984) system also includes adjustments for the effects of growth stimulants and previous nutritional treatment and a special factor for Holstein cattle; it is shown to be effective in predicting the growth of various types of cattle (including some Charolais crosses), but it does not cater for bulls.

When this review was in its final stages of preparation, there arrived in Britain a new (sixth) edition of the United States publication Nutrient Requirements of Beef Cattle (National Research Council, 1984). This quotes net energy values for emptybody gain (i.e. energy values of gain) that are based on Garrett ( 1980 ), but include

Table 5. Energy content of empty-body gains of cattle (Mf/kg): comparison of two systems

Empty body-wt...

System $\bullet .$.

Sex

Heifer

Steer

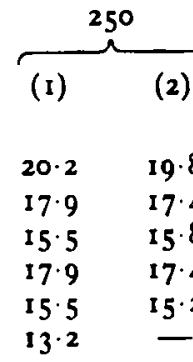

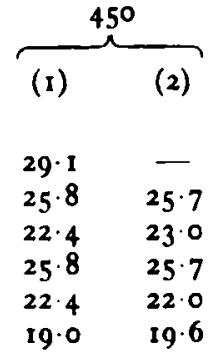

(1), Agricultural Research Council (1980); (2), Fox \& Black (1984); approximate values obtained by plotting values from Table 2. 
adjustments for breed size, etc. that appear to be similar to those of ARC (1980) and Fox \& Black (1984).

In Australia, complex simulation models have been derived to predict the growth (and also wool and milk production) of ruminants. These models give estimates of energy and nitrogen retention and use values for body composition to translate such estimates into changes in body-weight. In the initial model for sheep (Graham et al. 1976), the simple assumption was made that the composition of gain would be determined by the energy and $\mathrm{N}$ available for it. Later versions of the model include much more complex calculations (Black, I983; 1984). Thus the potential for energy storage is calculated from the maximum energy content of the animal at maturity and the degree of maturity achieved. Allowances are made for differences between breed-types and sexes. A similar approach has been adopted in South Africa (Roux \& Meissner, 1984).

\section{Conclusions}

Many papers on body composition of ruminants have been published in the last decade, and not all could be included in this short review. The major factors determining body composition have now been identified and reasonably well quantified, but there is still a need to combine these factors into simple predictive models. Ideally, such models should be capable of accommodating a wide range of information sources, not just those from one production system or one country. Nevertheless, it should now be feasible to identify and discard data sets that are biased or otherwise inapplicable to modern animal production. For example, from what is now known about protein digestion and metabolism in ruminants, it seems likely that animals in some comparative slaughter experiments were unable to express their full potential for protein deposition. Finally, as more becomes known about metabolism in ruminants and its regulation, it should be possible to make progress in the so-far relatively unexplored area of control of body composition by nutritional, endocrine and other means.

\section{REF ERENCES}

Agricultural Research Council (1980). Nutrient Requirements of Ruminant Livestock. Farnhem Royal: Commonwealth Agricultural Bureaux.

Baker, P. K., Dalrymple, R. H., Ingle, D. L. \& Ricks, C. A. (1984). Fournal of Animal Science 59, $1256-1261$.

Barry, T. N. (1981). British Fournal of Nutrition 46, 521-532.

Bauman, D. E. (1984). Proceedings of the Cornell Nutrition Conference, pp. 13-17.

Black, J. L. (1983). In Sheep Production, pp. $21-58$ [W. Haresign, editor]. London: Butterworths.

Black, J. L. (1984). In Herbivore Nutrition in the Subtropics and Tropics, pp. 648-67r [F. M. C. Gilchrist and R. I. Mackie, editors]. Pretoria: Science Press.

Burton, J. H. \& Reid, J. T. (1969). Fournal of Nutrition 97, 517-524.

Daenicke, R. \& Rohr, K. (1978). In Patterns of Growth and Development in Cattle, pp. 423-433

[H. E. Boer and J. Martin, editors]. The Hague: Nijhoff.

Daenicke, R., Rohr, K. \& Oslage, H. J. (1982). Livestock Production Science 8, 479-488. 
Dalrymple, R. H., Baker, P. K. \& Ricks, C. A. (1984). Proceedings of the Georgia Nutrition Conference pp. $111-118$.

Drew, K. R. \& Reid, J. T. (1975). Fournal of Agricultural Science, Cambridge 85, 193-204.

Ferrell, C. L., Course, J. D., Field, R. A. \& Chant, J. L. (1979). Fournal of Animal Science 49, $790-801$.

Flachowsky, G. (1979a). Archiv für Tierernährung 29, 17-26.

Flachowsky, G. (1979b). Archiv für Tierernährung 29, 27-35.

Foot, J. Z. \& Tulloh, N. M. (1977). Fournal of Agricultural Science, Cambridge 88, 135-142.

Fortin, A., Simpfendorfer, S., Reid, J. T., Ayala, H. J., Anrique, R. \& Kertz, A. F. (1980). fournal of Animal Science 51, 604-614.

Fox, D. T. \& Black, J. R. (1984). fournal of Animal Science 58, 725-739.

Galbraith, H. \& Topps, J. H. (1981). Nutrition Abstracts and Reviews 51B, 521-540.

Garrett, W. N. (1980). In Energy Metabolism European Association of Animal Production Publication no. 26, p. 3 [L. E. Mount, editor]. London: Butterworths.

Geay, Y. (1984). Fournal of Animal Science 58, 766-778.

Geay, Y. \& Robelin, J. (1979). Livestock Production Science 6, 263-276.

Graham, N. McC., Black, J. L., Faichney, G. J. \& Arnold, G. W. (1976). Agricultural Systems I, $113-13^{8}$.

Graham, N. McC. \& Searle, T. W. (1979). Australian fournal of Agricultural Research 30, $513-523,525-531$.

Greenhalgh, J. F. D. (1980). Proceedings of the Fourth Study Conference of the Scottish Agricultural Colleges, pp. I-14.

Haecker, T. L. (1920). Bulletin of the Minnesota Experimental Station, no. 193.

Jesse, G. W., Thompson, G. B., Clark, J. L., Hedrick, H. B. \& Weimer, K. G. (1976). Fournal of Animal Science 43, 418-425.

Meissner, H. H. (1983a). South African fournal of Animal Science 13, 80-83.

Meissner, H. H. (1983b). South African fournal of Animal Science 13, 267-276.

Moulton, C. R., Trowbridge, P. F. \& Haigh, L. D. (1922). Research Bulletin of the Missouri Agricultural Experimental Station, no. 55.

National Research Council (1984). Nutrient Requirements of Beef Cattle, 6th. ed. Washington DC: National Academy Press.

O'Donovan, P. B. (1984). Nutrition Abstracts and Reviews 54B, 389-410.

Price, M. A. (1975). Fournal of Agricultural Science, Cambridge 84, $201-208$.

Ricks, C. A., Dalrymple, R. H., Baker, P. K. \& Ingle, L. D. (1984). Fournal of Animal Science 59, $1247-1255$.

Robelin, J. (1979). Annales de Zootechnie 28, 209-21 8.

Robelin, J. \& Geay, Y. (1984). In Herbivore Nutrition in the Subtropics and Tropics, pp. 525-548 [F. M. C. Gilchrist and R. I. Mackie, editors]. Pretoria: Science Press.

Robelin, J., Geay, Y. \& Beranger, C. (1979). Annales de Zootechnie 28, $191-208$.

Robelin, J., Geay, Y. \& Bonaiti, B. (1978). In Patterns of Growth and Development in Cattle, pp. 443-460 [H. De Boer and J. Martin, editors]. The Hague: Nijhoff.

Robelin, J. \& Theriez, M. (1981). Reproduction, Nutrition et Développment 21, 335-353.

Rohr, K. \& Daenicke, R. (1984). Fournal of Animal Science 58, 753-765.

Roux, C. Z. \& Meissner, H. H. (1984). In Herbivore Nutrition in the Subtropics and Tropics, pp. 672-690 [F. M. C. Gilchrist and R. I. Mackie, editors]. Pretoria: Science Press.

Searle, T. W. (1970). Journal of Agricultural Science, Cambridge 75, 497-500.

Searle, T. W. \& Graham, N. McC. (1975). Australian fournal of Agricultural Research 26, $355-36 \mathrm{I}$.

Searle, T. W., Graham, N. McC. \& Donnelly, J. B. (1982). Fournal of Agricultural Science, Cambridge 98, $241-245$.

Simpfendorfer, S. ( (1984). PhD Thesis, Cornell University.

Spencer, G. S. G. (I985). Livestock Production Science 12, $31-46$.

Spencer, G. S. G., Garssen, G. J. \& Bergstrom, P. L. (1983). Livestock Production Science 10, 469-477.

Theriez, M., Tissier, M. \& Robelin, J. (198r). Animal Production 32, 29-37.

Theriez, M., Villette, Y. \& Castrillo, C. (1982). Livestock Production Science 9, 471-485.

Thompson, J. M., Butterfield, R. M. \& Perry, D. (1985). Animal Production 40, $71-84$. 
Thornton, R. F., Hood, R. L., Jones, P. M. \& Re, V. M. (1979). Australian Yournal of Agricultural Research $30,135^{-1} 5^{1}$.

Truscott, T. G., Wood, J. D. \& MacFie, H. J. H. (1982). Fournal of Agricultural Science, Cambridge 100, 257-270.

Tudor, G. D., Utting, D. W. \& O'Rourke, P. K. (Ig80). Australian Fournal of Agricultural Research 3I, 19I-204.

Waldo, D. R. \& Tyrrell, H. F. (1980). Proceedings of the 3rd EAAP Symposium on Protein Metabolism and Nutrition, publication no. 27, vol. 2, pp. 572-576 [H. J. Oslage and K. Rohr, editors]. Braunschweig, Federal Republic of Germany: European Association of Animal Production. 